\title{
PENGARUH BEBAN KERJA TERHADAP TINGKAT KELELAHAN PEGAWAI TIDAK TETAP (PTT) KANTOR KECAMATAN TANJUNG KARANG TIMUR KOTA BANDAR LAMPUNG
}

\author{
Muhammad Herowandi \\ herowandi@utb.ac.id \\ Program Studi Administrasi Publik, Fakultas Ilmu Sosial dan Ilmu Politik, UTB Lampung
}

\begin{abstract}
ABSTRAK
Sumber daya manusia merupakan asset utama organisasi yang menjadi perencana dan pelaku aktif dari setiap aktivitas organisasi. Kebutuhan sumber daya manusia yang memiliki kualitas dan kuantitas yang baik seharusnya disesuaikan dengan kebutuhan organisasi supaya dalam mendukung tercapainya suatu tujuan organisasi dapat terselenggara dengan efektif dan efisien. Kantor Kecamatan adalah salah satu kecamatan yang terletak di Kota Bandar Lampung. Untuk pelaksanaan tugas pokok dan fungsi di Kecamatan perlu ditingkatkan sumber daya manusianya dan dukungan sarana prasarana. Setiap pegawai memiliki beban kerja yang bervariasi, mengingat banyaknya jumlah aparatur dengan status kepegawaian. Fokus dalam penelitian ini adalah mengenai beban kerja pegawai tidak tetap, secara umum para pegawai tidak tetap biasanya untuk usia ratarata masih muda dalam aparatur sipil negara. Dan mereka memiliki jiwa semangat dan loyalitas yang tinggi untuk harapan bisa diangkat menjadi aparatur sipil negara. Sehingga dapat ditemukan hasil dari penelitian ini mengenai tingkat beban kerja yang diterima para pegawai tidak tetap Kantor Kecamatan Tanjung Karang Timur Kota Bandar Lampung.
\end{abstract}

Kata Kunci: Pengaruh Beban Kerja, Tingkat Kelelahan, Pegawai Tidak Tetap (PTT)

\section{PENDAHULUAN}

Pada dasarnya setiap organisasi memiliki visi dan misi untuk mencapai tujuan dalam suatu organisasi. Dalam mencapai tujuan tersebut, sebuah organisasi baik organisasi di lingkungan pemerintah maupun organisasi swasta membutuhkan sumber daya manusia yang mempuni. Hal ini terjadi agar dalam mencapai keberhasilan dari tujuan organisasi manusia yang merupakan faktor utama dalam setiap kegiatan organisasi bisa mempengaruhi faktor pendukung lainnya untuk itu, dalam sebuah organisasi diharapkan memiliki sumber daya manusia yang profesional, berdedikasi tinggi, dan loyal.

Sumber daya manusia merupakan asset utama organisasi yang menjadi perencana dan pelaku aktif dari setiap aktivitas organisasi. Kebutuhan sumber daya manusia yang memiliki kualitas dan kuantitas yang baik seharusnya disesuaikan dengan kebutuhan 
organisasi supaya dalam mendukung tercapainya suatu tujuan organisasi dapat terselenggara dengan efektif dan efisien.Pengadaan tenaga kerja merupakan langkah pertama dan yang mencerminkan berhasil tidaknya suatu perusahaan mencapai tujuannya, Hal tersebut sejalan dengan pendapat Sedarmayanti (2009) yang menyatakan bahwa "Pengadaan adalah proses seleksi, penarikan, penempatan orientasi dan induksi untuk mendapatkan pegawai yang sesuai dengan kebutuhan organisasi." Kebutuhan tenaga kerja tidak sesuai dengan tersedianya pegawai pada suatu organisasi pemerintah. PNS (Pegawai Negeri Sipil) adalah pegawai pada organisasi pemerintah. Beban kerja PNS tidak sesuai dengan beban kerja yang dikerjakan, hal tersebut sering terjadi dalam oranisasi pemerintah.

Oleh karena itu, untuk melengkapi kebutuhan tenaga kerja di lingkungan pemerintah memiliki tujuan agar dapat mencapai melancarkan penyelenggaraan pemerintah tersebut. Pegawai tidak tetap (PTT) yang penghasilannya menjadi beban APBD diangkat oleh pemerintah (Pejabat Pembina Kepegawaian). PTT yang selanjutnya disingkat PTT merupakan pegawai yang diangkat atau dipekerjakan dengan sistem kontrak dalam jangka waktu 1 (satu) tahun dan dapat diperpanjang guna melaksanakan tugas pemerintah, pembangunan serta pelayanan masyarakat yang bersifat teknis, profesional dan administrasi sesuai dengan kebutuhan dan kemampuan Pemerintah Kota dan diberikan penghasilan yang bersumber dari APBD.

Dalam melaksanakan tugas pada sebuah organisasi, PTT tersebut sangat dibutuhkan. Bagi PTT jelas bahwa gaji yang diterima tidak lebih besar dari gaji PNS. Seharusnya pekerjaan PNS lebih banyak dibandingkan dengan PTT. Namun, pada PTT lebih banyak menjelaskan tugas dan beban pekerjaan yang seharusnya diselesaikan dibanding dengan beban kerja yang diselesaikan oleh PNS. Karena berbagai faktor hal tersebut terjadi.

Banyaknya beban kerja yang diterima oleh PTT hal itu merupakan Faktor yang seringkali ditemukan. Banyaknya beban pekerjaan PTT ini diuraikan dengan jelas pada Peraturan Walikota Nomor 146 Tahun 2018 yaitu menghimpun bahan penyusunan Laporan Keuangan Semesteran dan Akhir Tahun Anggaran pada SKP sesuai lingkup tugasnya, mengadministrasikan bahan penyusunan Laporan Keuangan Semesteran dan Akhir Tahun Anggaran pada SKPD sesuai dengan lingkup tugasnya, membantu Pejabat Penatausahaan Keuangan SKP dalam proses jurnal akuntansi pada setiap transaksi yang terjadi pada SKPD, membantu Pejabat Penatausahaan Keuangan SKP meneliti, mengoreksi dan pembetulan-pembetulan atas kesalahan yang terdapat pada draft Laporan Keuangan Semesteran dan Akhir Tahun Anggaran pada SKPD sebelum menjadi dokumen yang sah, 


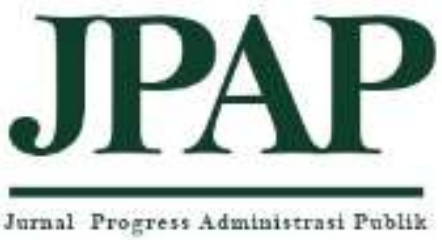

Volume 1 Nomor 2 melaksanakan rekonsiliasi dengan Satuan Pengelola Keuangan Lainnya (Bendahara Penerimaan, Bendahara Pengeluaran dan Operator SIMRAL Keuangan dan Barang) pada SKPD, membantu penyusunan Laporan Keuangan SKP, dan membantu penyusunan Catatan atas Laporan Keuangan SKPD.

Walaupun secara fisik pegawai tersebut kuat dan meskipun hebatnya kemampuan pegawai tersebut tetap saja tidak bisa bekerja dengan begitu banyak beban kerja yang harus ditanggung. Seorang pegawai tidak akan mampu bekerja sendirian karena semua harus mendapatkan beban tanggung jawab tersendiri. Dalam Pencapaian suatu tujuan organisasi tidak ada seorangpun yang mampu bekerja secara personal. Pada dasarnya Pekerjaan akan terselesaikan dengan baik dan tepat waktu dengan adanya beban kerja yang diberikan pada masing-masing pegawai. Sehingga, beban kerja pegawai adalah suatu hal yang penting untuk diperhatikan dan disesuaikan sesuai dengan kemampuan yang dimiliki oleh setiap pegawai. Menurut Kadek Ferrania Paramitadewi (2017) pada penelitian terdahulu yang menyatakan bahwa semakin rendah beban kerja pegawai maka semakin tinggi kinerja pegawai.

Permendagri No.12 Tahun 2008 menjabarkan bahwa beban kerja yang dibebankan kepada pegawai dapat dikategorikan kedalam tiga kondisi, yaitu beban kerja yang sesuai standar, beban kerja yang terlalu tinggi (over capacity) dan beban kerja yang terlalu rendah (under capacity). Ketiga jenis beban kerja tersebut dapat terjadi tergantung pada deskripsi pekerjaan yang telah disusun oleh perusahaan. Semakin banyak deskripsi yang diberikan, maka semakin besar kemungkinan terjadinya over capacity, dan demikian sebaliknya. Tinggi rendahnya beban kerja juga bergantung dari penggunaan teknologi. Semakin banyak teknologi yang digunakan sebagai penunjang dalam menyelesaikan pekerjaan, maka semakin ringan beban kerja seorang karyawan. Over capacity dan under capacity akan berdampak negatif bagi instansi tersebut, terutama terhadap efektivitas tenaga kerja. Terjadinya over capacity dapat menyebabkan menurunnya kondisi mental maupun fisik karena kelelahan yang dialami dan kurangnya waktu istirahat yang dibutuhkan, sedangkan jika terjadi under capacity maka instansi memerlukan pegawai dengan jumlah yang banyak, jika tidak demikian maka waktu penyelesaian pekerjaan akan menimbulkan keterlambatan.

Secara umum, faktor yang kompleks, baik faktor internal maupun eksternal dapat mempengaruhi beban kerja seseorang. (Tarwaka, dkk:2004). Faktor psikis (persepsi, motivasi, kepercayaan, dan kepuasan) dan Faktor internal beban kerja seperti faktor somatis (umur, jenis kelamin, ukuran tubuh, dan status gizi). Sedangkan 
kondisi lingkungan kerja seperti lingkungan kerja kimia, fisik, biologis, dan psikologis dan faktor eksternal beban kerja seperti tugas-tugas (kompleksitas pekerjaan, tanggung jawab dan sebagainya), organisasi kerja (sistem kerja. waktu kerja, shift kerja, dan sarana kerja).

Salah satu instansi yang berada di Kota Bandar Lampung adalah Kantor Kecamatan. Sarana prasarana dan dukungan sumber daya manusia yang memadai baik dari segi kualitas maupun kuantitas diperlukan dalam rangka melaksanakan tugas pokok dan fungsi (tupoksi). Banyaknya jumlah aparatur yang mendukung dan status kepegawaian maka beban kerja yang diterima masing-masing pegawai juga bervariasi. Fokus penelitian ini pada beban kerja pegawai tidak tetap karena pada umumnya pegawai tidak tetap merupakan pegawai dengan usia yang relatif lebih muda dari aparatur sipil negara dan memiliki semangat serta loyalitas tinggi. Besar harapan diangkatnya status pegawai tidak tetap menjadi aparatur sipil negara, sehingga dari penelitian ini dapat diketahui tingkat beban kerja yang diterima oleh pegawai tidak tetap Kantor Kecamatan Tanjung Karang Timur Kota Bandar Lampung.

Berdasarkan uraian diatas penulis tertarik untuk membuat penelitian berjudul "Pengaruh Beban Kerja terhadap Tingkat Kelelahan Pegawai Tidak Tetap (PTT) Kantor Kecamatan Tanjung Karang Timur Kota Bandar Lampung".

\section{TINJAUAN TEORI}

\subsection{Pengertian Beban Kerja}

Beban kerja merupakan suatu hal yang harus diperhatikan oleh setiap organisasi, karena beban kerja menjadi salah satu faktor yang dapat mempengaruhi kinerja karyawan, dan kualitas istirahat para pegawainya.

Menurut Undang-Undang Kesehatan No.36 Tahun 2009, pengertian beban kerja merupakan suatu besaran pekerjaan yang harus dipikul oleh suatu jabatan/unit organisasi dan merupakan hasil kali antara jumlah pekerjaan dengan waktu. Setiap pekerja dapat bekerja secara sehat tanpa membahayakan dirinya sendiri maupun masyarakat di sekelilingnya, untuk itu perlu dilakukan upaya penyerasian antara kapasitas dalam bekerja, besaran beban kerja serta lingkungan kerja agar diperoleh produktivitas kerja yang optimal.

Definisi beban kerja adalah sejumlah atau sekumpulan kegiatan yang harus diselesaikan oleh suatu unit organisasi atau pemegang jabatan dalam jangka waktu tertentu menurut Kementerian

Pendayagunaan Aparatur Negara / Menpan (1997), Sedangkan menurut Robbins (2003) menyatakan bahwa positif atau negatifnya beban kerja merupakan masalah persepsi. Dimana persepsi mengenai beban kerja berkaitan dengan faktor atribut peran dan pekerjaan. Hal ini dikarenakan 


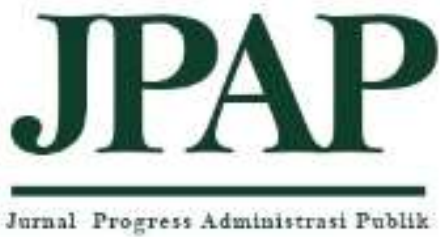

Juraal Progress Administrasi Publik

Volume 1 Nomor 2 persepsi mengenai beban kerja terhubung dengan suatu pekerjaan, dimana seseorang memberikan penilaian mengenai sejumlah tuntutan tugas atau kegiatan yang membutuhkan aktivitas fisik dan mental yang harus ia selesaikan dalam waktu tertentu, apakah pekerjaannya tersebut memiliki dampak positif atau negatif.

Berdasarkan definisi di atas, maka dapat diambil suatu kesimpulan bahwa beban kerja merupakan sejauh mana kemampuan seseorang pekerja/pegawai yang digunakan dalam menyelesaikan tugas yang diberikan dan dapat diindikasikan dari jumlah pekerjaan yang diterima, batasan waktu yang dimiliki oleh pekerja/pegawai untuk dapat menyelesaikan pekerjaannya.

\subsection{Faktor-faktor yang Mempengaruhi Beban Kerja}

Berikut ini merupakan beberapa faktor yang dapat mempengaruhi beban kerja, dijelaskandalam penelitian yang dilakukan oleh Lalu Ciptadi Romadhoni et.al. ((2015) adalah sebagai berikut:

1) Faktor eksternal yaitu beban kerja yang berasal dari luar tubuh pekerja yaitu (a). Tugas (task). Seperti tugas bersifat fisik yaitu, penataan Surat Pertanggungjawaban (SPJ), penyusunan laporan keuangan, memberikan pelayanan setiap hari kepada semua masyarakat Kecamatan Tanjung Karang Timur Kota Bandar Lampung Sedangkan tugas yang bersifat mental meliputi, tanggung jawab, kompleksitas pekerjaan, emosi pekerjaan dan sebagainya. (b). Organisasi Kerja. Meliputi lamanya waktu kerja, waktu istirahat, lamanya memberikan pelayanan kepada masyarakat, dan sebagainya. (c). Lingkungan Kerja. Lingkungan kerja tersebut dapat memberikan beban tambahan seperti, lingkungan kerja kimiawi, lingkungan kerja fisik, lingkungan kerja biologis dan lingkungan kerja psikologis.

2) Faktor Internal. Faktor Internal ini berasal dari dalam tubuh akibat reaksi beban kerja eksternal yang berpotensi sebagai stesor. Adapun faktor internal meliputi faktor psikis (motivasi persepsi, kepercayaan, keinginan, kepuasan, dan sebagainya).

\subsection{Dampak Beban Kerja}

Kemampuan fisik yang terlalu lemah ditambah dengan beban kerja yang terlalu berat dapat mengakibatkan seorang pekerja menderita gangguan atau penyakit. Kondisi lingkungan kerja (panas, bising, debu, ataupun terlalu dingin) dapat mengakibatkan beban tambahan terhadap pegawai. Faktor yang 
memiliki hubungan maupun yang tidak memiliki hubungan secara langsung dengan pekerjaan dapat menimbulkan gangguan kesehatan pada pekerja.

\subsection{Pengukuran Beban Kerja}

Pada umumnya. pengukuran beban kerja biasa diartikan sebagai suatu teknik untuk mendapatkan informasi tentang efisiensi dan efektivitas kerja suatu unit organisasi, atau pemegang jabatan yang dilakukan secara sistematis dengan menggunakan teknik analisis beban kerja, teknik analisis jabatan dan teknik manajemen lainnya. Salah satunya yaitu Full Time Equivalent (FTE). Ada beberapa definisi tentang Full Time Equivalent (FTE), menurut Dewi dan Satrya (2012) FTE merupakan salah satu metode analisis beban kerja yang berbasiskan waktu dengan cara mengukur lama waktu penyelesaian pekerjaan kemudian waktu tersebut dikonversikan ke dalam indeks nilai FTE.

Metode perhitungan beban kerja dengan full time equivalent (FTE) merupakan metode dimana waktu yang digunakan untuk menyelesaikan berbagai pekerjaan dibandingkan terhadap FTE bertujuan menyederhanakan pengukuran kerja dengan mengubah jam beban kerja ke jumlah orang yang dibutuhkan untuk menyelesaikan pekerjaan tertentu (Adawiyah W., 2013).
Menurut Oesman(2012) FTE merupakan sebuah cara untuk menghitung jumlah orang di suatu populasi atau organisasi. FTE adalah suatu cara untuk mengukur orang yang bekerja full time (Sesuai standar yang ditetapkan) sehingga merupakan jumlah aktual jam kerja sebagai seorang pegawai tetap (full time employee). FTE juga merupakan rasio yang dapat menggambarkan jumlah jam dimana seorang karyawan bekerja selama 40 jam. Dengan kata lain, jumlah jam kerja karyawan per 40 jam tersebut diasumsikan selama 1 minggu. Dewi dan Satrya(2012) mengungkapkan implikasi dari nilai FTE terbagi menjadi 3 (tiga) jenis yaitu overload, normal dan underload. Badan Kepegawaian Negara mengeluarkan pedoman analisis beban kerja pada tahun 2010, total nilai indeks FTE yang berada di atas nilai 1.28 dianggap normal sedangkan, jika nilai indeks FTE berada di antara nilai 0 sampai dengan 0,99 dianggap underload atau beban kerjana masih kurang. Untuk mendapatkan nilai FTE dari suatu proses kerja yaitu sebagai berikut:

FTE = Total working hours / year + Allowance (1) Effective working hours / year.

Dalam melakukan sebuah analisis terhadap beban kerja, Dewi dan Satrya (2012) menggunakan metode FTE (Full Time Equivalent) dengan melakukan lima (5) langkah dibawah ini: 


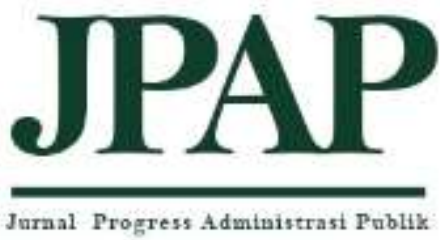

Juraal Progress Administrasi Publi

Volume 1 Nomor 2 a) Menetapkan unit kerja beserta kategori tenaganya.

b) Menetapkan waktu kerja yang tersedia selama satu tahun. Hari kerja, cuti tahunan, pendidikan dan pelatihan, hari libur nasional, ketidakhadiran kerja, dan waktu kerja merupakan beberapa data yang harus dilengkapi untuk menetapkan waktu kerja dalam setahun.

c) Menyusun standar kelonggaran. Faktor kelonggaran (allowance) karyawan seperti kegiatan dan kebutuhan waktu dalam menyelesaikan suatu kegiatan yang tidak terkait dengan kegiatan pokoknya merupakan suatu tujuan dari penyusunan data ini.Adapun beberapa kegiatan yang tidak terkait secara langsung seperti istirahat, sholat atau ke toilet dan lain sebagainya.

d) Menetapkan standar beban kerja. Volume beban kerja yang dirasakan oleh karyawan dalam menyelesaikan pekerjaannya (rata-rata waktu) merupakan pengertian dari standar beban kerja.

e) Menghitung kebutuhan tenaga per unit kerja. Jumlah karyawan dan kategori karyawan yang bekerja sesuai dengan adanya beban kerja berusaha diperoleh dalam tahap ini.

\subsection{Beban Kerja Pegawai Tidak Tetap}

Menpan (1997) mengartikan beban kerja sebagai sejumlah kegiatan atau sekumpulan pekerjaan yang harus diselesaikan oleh suatu unit organisasi atau pemegang jabatan dalam jangka waktu tertentu.Sebagai salah satu unsur organisasi, Pegawai Tidak Tetap memiliki beberapa rangkaian kegiatan yang harus diselesaikan dalam jangka waktu yang telah ditentukan.

Adapun beban kerja atau tugas yang dimiliki oleh Pegawai Tidak Tetap adalah menghimpun bahan penyusunan Laporan Keuangan Semesteran dan Akhir Tahun Anggaran pada SKPD sesuai dengan Lingkup tugasnya, mengadministrasikan bahan penyusunan Laporan Keuangan Semesteran dan Akhir Tahun Anggaran pada SKPD sesuai dengan lingkup tugasnya, membantu Pejabat Penatausahaan Keuangan SKPD dalam proses jurnal akuntansi pada setiap transaksi yang terhadap pada SKPD, membantu Pejabat Penatausahaan Keuangan SKPD meneliti, mengoreksi, dan pembetulan-pembetulan atas kesalahan yang terdapat pada draft Laporan Keuangan Semesteran dan Akhir Tahun Anggaran pada SKPD sebelum menjadi dokumen yang sah, melaksanakan rekonsiliasi dengan Satuan Pengelola Keuangan Lainnya (Bendahara Penerimaan, Bendahara Pengeluaran dan Operator SIMRAL Keuangan dan Barang) pada SKPD, membantu penyusunan Laporan Keuangan SKPD dan membantu 
penyusunan Catatan atas Laporan Keuangan SKPD.

\subsection{Pengertian Kelelahan}

Bergerak merupakan salah satu ciri manusia sebagai makhluk hidup. Setiap pergerakan yang mereka lakukan memiliki alasan dan tujuan tersendiri. Adapun pergerakan yang kerap kali dilakukan sebagai rutinitas keseharian yaitu adalah dengan bekerja. Apabila dalam waktu lama kita melakukan suatu pekerjaan baik itu pekerjaan yang berhubungan langsung dengan pekerjaan fisik atau tidak, tetapi pekerjaan tetaplah pekerjaan yang akan tetap menimbulkan kelelahan.

Terdapat beberapa pengertian kelelahan kerja, antara lain Suma`mur (2009) Kelelahan adalah mekanisme perlindungan tubuh agar tubuh menghindari kerusakan lebih lanjut, sehingga dengan demikian terjadilah pemulihan. Setiap individu, menunjukkan kondisi kelelahan yang berbeda-beda, tetapi semuanya bermuara pada ketahanan tubuh yang kehilangan efisiensi dan penurunan kapasitas kerja (Tarwaka, 2010). Kelelahan kerja dapat menurunkan kinerja dan menambah tingkat kesalahan kerja (Nurmianto, 1996).

Suma`mur(2009) memaparkan bahwa tanda-tanda kelelahan yang utama adalah hambatan terhadap fungsi kesadaran otak dan adanya beberapa perubahan pada beberapa bagian organ di luar kesadaran serta proses pemulihan. Adapun indikator kelelahan kerja yaitu sebagai berikut:

- Perhatian yang menurun.Menurunnya perhatian yang disebabkan karena timbulnya rasa sakit di kepala, menjadikan lelah seluruh badan, hingga kaki merasa berat, sering menguap, merasa kacau pikiran, menjadi mengantuk, merasakan beban pada mata, kaku dan canggung dalam gerakan, tidak seimbang dalam berdiri, mau berbaring.

- Persepsi melambat dan menghambat seperti merasa susah berpikir, lelah berbicara, menjadi gugup, tidak berkonsentrasi, tidak dapat mempunyai perhatian terhadap sesuatu, cenderung untuk lupa, kurang kepercayaan, cemas terhadap sesuatu, tidak dapat mengontrol sikap, tidak dapat tekun dalam pekerjaan.

- Kemampuan berprestasi menurun yaitu pekerja yang mengalami kelelahan kerja akan berprestasi lebih buruk lagi daripada pekerja yang masih penuh semangat.

- Kegiatan mental dan fisik menjadi kurang efisien yakni kelelahan adalah aneka keadaan yang disertai penurunan efisiensi dan ketahanan dalam bekerja. Kelelahan kerja akan menurunkan kinerja dan menambah tingkat kesalahan kerja, sehingga membuat kegiatan mental dan fisik menjadi kurang efisien. 


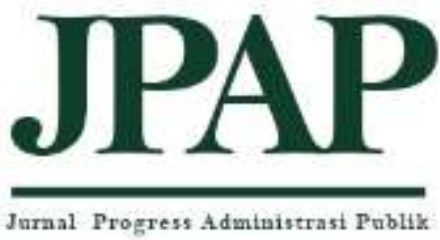

Volume 1 Nomor 2

\subsection{Jenis Kelelahan}

S. Wignjosubroto (2003) memaparkan pembagian atas jenis kelelahan kerja menurut proses pada otot, waktu terjadinya dan penyebab kelelahan itu sendiri. Menurut proses pada otot kelelahan kerja terbagi atas, kelelahan umum dan kelelahan otot. Kelelahan otot adalah menurunnya kemampuan otot untuk melakukan suatu aktifitas, ditandai dengan munculnya tremor atau rasa nyeri yang terdapat pada otot. Sedangkan kelelahan umum adalah suatu perasaan kelelahan yang menyebar, disertai adanya penurunan kesiagaan dan keterlambatan pada setiap aktifitasnya, yang disebabkan oleh kondisi psikispsikologis ataupun karena keadaan persyarafan sentral.

Menurut waktu terjadinya kelelahan kerja dapat diuraiakan menjadi kelelahan akut dan kelelahan kronis. Kelelahan akut adalah kelelahan yang dapat timbul akibat kerja secara berlebihan. Sedangkan kelelahan kronis merupakan kelelahan yang timbul akibat sejumlah faktor yang terakumulasi dan berlangsung secara terus-menerus. Adapun Gejala-gejala yang terlihat akibat lelah kronis bisa dicirikan seperti meningkatnya rasa emosi dan rasa jengkel sehingga seseorang menjadi tidak toleransi atau asosiasi terhadap orang lain, muncul sikap apatis terhadap orang lain, depresi berat, dan lain-lain.
Menurut penyebabnya kelelahan kerja dibagi atas kelelahan fisik dan kelelahan non fisik. Kelelahan fisik timbul karena disebabkan oleh faktor fisik, sedangkan kelelahan non fisik timbul karena disebabkan oleh faktorfaktor non fisik seperti adanya problema psikososial dalam keluarganya, tempat kerjany,a maupun dalam masyarakat di lingkungan tempat tinggalnya.

Depkes RI (2007) membagi jenis kelelahan menjadi tiga jenis yaitu kelelahan fisik, kelelahan yang Patologis, dan Psikologis dan emotional Fatique. Kelelahan Fisik terjadi karena kerja yang berlebihan, dimana masih dapat dikompensasi dan diperbaiki performannya seperti sediakala.Istirahat dan tidur yang cukup dapat menghilangkan kelelahan fisik yang tidak terlalu berat. Sedangkan, Kelelahan yang Patalogis adalah kelelahan yang tergabung dengan penyakit yang diderita, biasanya muncul tiba-tiba dan berat gejalanya. Sedangkan Psikologis dan Emotional Fatiqueadalah jenis kelelahan yang umum. Kemungkinan jenis mekanisme melarikan diri dari kenyataan pada penderita psikosomatik.

\subsection{Penyebab Kelelahan}

Kondisi kerja yang berulang-ulang dapat menimbulkan suasana monoton yang berakumlasi menjadi rasa bosan, dimana rasa bosan dikategorikan 
sebagai kelelahan (Nurmianto, 1996).

Faktor Psikologis juga memiliki peranan yang besar dalam menimbulkan kelelahan. Seringkali para pekerja yang tidak mengerjakan apapun, tetapi mereka tetap merasa lelah sebab adanya tanggung jawab, kecemasan dan konflik (Suma`mur, 2009).

\subsection{Faktor yang Mempengaruhi Tingkat Kelelahan}

Beberapa faktor penyebab yang mempengaruhi tingkat kelelahan yaitu:

\section{1) Usia}

Usia seseorang merupakan faktor utama yang dapat mempengaruhi tingkat kelelahan. Semakin tua usia pegawai maka tingkat kelelahan yang dirasakan akan semakin meningkat dibandingkan pegawai dengan usia yang lebih muda dengan beban kerja yang sama.

2) Beban dan lamanya pekerjaan (baik fisik maupun mental)

Aktivitas yang sifatnya berat dapat menjadikan seseorang lebih sering istirahat dan mengakibatkan waktu kerja yang dimiliki menjadi lebih pendek. Pada akhirnya, kelelahan akan timbul apabila aktivitas diperpanjang atau diperbanyak melebihi kemampuannya. Semakin tinggi intensitas suatu aktivitas maka waktu yang dibutuhkan semakin pendek, frekuensi istirahatpun menjadi semakin banyak (PK, 1989).

\section{METODE}

Pada penelitian ini menggunakan metode explanatory research, metode ini menjelaskan hubungan antara variabel-variabel melalui pengujian hipotesis yang telah dirumuskan. Selanjutnya penelitian ini menggunakan metode cross sectional. Saat waktu yang bersamaan, data yang menyangkut variabel bebas dan variabel terikat dikumpulkan. Penentuan kejadian kelelahan berdasarkan gambaran keluhan subyektif yang dirasakan responden selama bekerja. Dan peristiwa tersebut dan diukur dengan kuesioner.

\section{ANALISIS HASIL DAN PEMBAHASAN}

Pegawai Tidak Tetap Kantor Kecamatan Tanjung Karang Timur Kota Bandar Lampung. Untuk melancarkan penyelenggaraan pemerintahan Kantor Kecamatan Tanjung Karang Timur Kota Bandar Lampung dalam menjalankan tugas pokok dan fungsinya (tupoksi) diperlukan sarana prasarana serta dukungan sumber daya manusia yang memadai baik dari segi kualitas maupun kuantitas. Aparatur yang mendukung pelaksanaan tugas pokok dan fungsi sebagian besar tersebar di enam kelurahan. Aparatur secara keseluruhan 


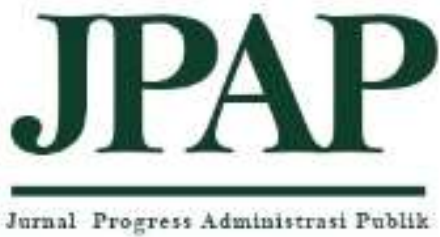

Juraal Progress Administrast Publik

Volume 1 Nomor 2 total 109 orang dengan status kepegawaian yang beragam mulai dari Aparatur Sipil Negara (ASN), Tenaga kontrak dan Pegawai Tidak Tetap (PTT) dengan ASN sejumlah 68 orang, Tenaga Kontrak 1 Orang, dan Pegawai Tidak Tetap sebanyak 40 orang.

Pegawai Tidak Tetap di lingkungan Pemerintah Kota Bandar Lampung telah memiliki kepastian hukum sejak di terbitkannya Peraturan WaliKota Bandar Lampung Nomor 57 Tahun 2015 tentang Pedoman Penataan Pegawai Tidak Tetap yang telah berubah sebanyak 3 (tiga) kali dengan perubahan terakhir terdapat Dalam Peraturan WaliKota Bandar Lampung Nomor 87 Tahun 2017 tentang Perubahan Ketiga atas Peraturan WaliKota Bandar Lampung Nomor 57 Tahun 2015 tentang Pedoman Penataan Pegawai Tidak Tetap. Pada Peraturan WaliKota Bandar Lampung tersebut Pegawai Tidak Tetap yang selanjutnya disingkat PTT merupakan seorang pegawai yang diangkat atau dipekerjakan dengan sistem kontrak untuk jangka waktu 1 (satu) tahun dan dapat diperpanjang guna melaksanakan tugas pemerintahan, pembangunan dan pelayanan masyarakat yang bersifat teknis, profesional dan administrasi sesuai dengan kebutuhan dan kemampuan Pemerintah Kota dan diberikan penghasilan yang bersumber dari APBD.

Pegawai Tidak Tetap di Kantor Kecamatan Tanjung Karang Timur Kota Bandar Lampung memiliki peran yang cukup penting dalam guna melancarkan tugas dan fungsi Kantor Kecamatan Tanjung Karang Timur Kota Bandar Lampung. Dari segi formasi PTT, Pegawai Tidak Tetap tersebar di beberapa bagian ada di bidang pelayanan, di bagian keuangan, dan di bagian administrasi. Dalam pelaksanaannya, PTT cukup bisa diandalkan karena adanya perjanjian kerja, pembinaan dan usia yang relatif muda maka, energi dan semangat mereka untuk menyelesaikan pekerjaan yang telah dibebankan kepadanya bisa dikerjakan dan diselesaikan sesuai dengan waktu yang telah di tentukan.

Hubungan Beban Kerja dengan Tingkat Kelelahan Pegawai Tidak Tetap (PTT) Kantor Kecamatan Tanjung Karang Timur Kota Bandar Lampung. Dalam melakukan aktivitas, setiap pegawai memiliki beban kerja yang telah ditetapkan. Namun, dalam pelaksanaannya, pegawai Kantor Kecamatan Tanjung Karang Timur Kota Bandar Lampung terbagi dalam dua jenis pegawai. Yang pertama adalah Aparatur Sipil Negara yang selanjutnya disingkat ASN adalah profesi bagi pegawai negeri sipil dan pegawai pemerintah dengan perjanjian kerja yang bekerja pada instansi pemerintah. Sedangkan Pegawai Negeri Sipil yang selanjutnya disingkat PNS adalah warga negara Indonesia yang memenuhi syarat tertentu, diangkat sebagai Pegawai ASN secara tetap oleh pejabat pembina kepegawaian untuk menduduki jabatan pemerintah. PNS ini adalah orang-orang yang telah diangkat 
untuk mengabdikan hidupnya sebagai Pegawai Negeri Sipil. Pada umumnya PNS diangkat dengan melalui tes secara langsung dan memiliki jumlah pesaing yang sangat banyak atau karena masa mengabdi yang relatif lama maka seseorang diangkat menjadi PNS. Karena itulah, mengapa rata-rata umur PNS pada saat ini lebih didominasi oleh kepala tiga atau sekitar umur 30 th keatas. Berbeda dengan pegawai tidak tetap (PTT) pada Kantor Kecamatan Tanjung Karang Timur Kota Bandar Lampung, biasanya diangkat dengan Surat Keputusan Kepala Kantor/Dinas/Badan yang diketahui oleh Bupati/Walikota setempat yang dialokasikan dari data APBD (Anggaran Pendapatan Belanja Daerah). Biasanya, PTT diambil dari golongan fresh graduate yang sangat berpotensi untuk membantu para PNS dalam menyelesaikan tugas-tugas yang ada di Kantor. Tetapi, karena adanya perbedaan inilah maka, pada pelaksanaan tugas, PTT lebih banyak menerima beban kerja jika dibandingkan dengan PNS. Bahkan terkadang seorang PTT dapat melakukan tugas 2-3 orang seorang PNS, sehingga beban kerja yang diterima PTT Kantor Kecamatan Tanjung Karang Timur Kota Bandar Lampung dapat menimbulkan kelelahan baik fisik dan mental.

\section{PENUTUP}

Karakteristik responden penelitian terdiri dari 57 orang perempuan (54\%) dan 43 orang laki-laki (43\%). Responden terbanyak berusia 23-28 tahun yakni sekitar 29\%. Selain itu, masa kerja responden terbanyak adalah sekitar 4-7 tahun yaitu sebesar $70 \%$.

Secara simultan beban kerja berpengaruh terhadap tingkat kelelahan Pegawai Tidak Tetap Kantor Kecamatan Tanjung Karang Timur Kota Bandar Lampung. Hal ini di buktikan dengan pernyataan, jika $\mathrm{F}$ hitung $\geq$ $F$ Tabel atau signifikan $<0,05$. Kemudian, karena hasil $\mathrm{F}$ hitung lebih besar dari $\mathrm{F}$ tabel yakni $2.989>0,05$ maka $\mathrm{Ha}$ diterima. Artinya, terdapat hubungan antara beban kerja dan tingkat kelelahan kerja di lokasi penelitian. Sehingga tingkat signifikan yaitu sebesar 2.989 .

\section{REFERENSI}

Arikunto, S. (2010). Prosedur Penelitian Suatu Pendekatan Praktik. Jakarta: Rineka Cipta.

Arikunto, S. (2010). Prosedur Penelitian Suatu Pendekatan Praktik. Jakarta: Rineka Cipta.

Dewi, U., \& Satrya, A. (2012). Analisis Kebutuhan Tenaga Kerja Berdasarkan Beban Kerja Karyawan pada PT PLN (Perseri) Distribusi Jakarta Raya dan Tangerang Bidang Sumber Daya Manusia dan Organisasi. Depok: Universitas Indonesia.

Paramitadewi, K. F. (2017). Pengaruh Beban Kerja dan Kompensasi Terhadap Kinerja Pegawai Sekretariat Pemerintah Daerah Kabupaten Tabanan, 6.

PK, S. (1989). Ergonomi untuk Produktivitas. Jakarta: CV. Haji Mas Agung. 


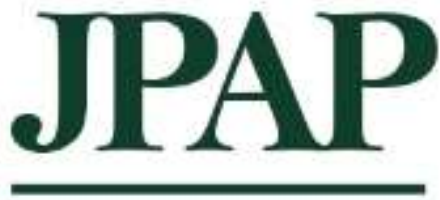

Juraal Progress Administrast Publik

Volume 1 Nomor 2

RI, D. (2007). Ergonomi. Retrieved from http://www.depkes.go.id/downlo ad/ergonomic.

Sedarmayanti. (2009). Sumber Daya Manusia dan Produktivitas Kerja. Bandung: CV. Mandar Maju.

Setiawan, D. P. (2016). Pengaruh Beban Kerja dan Lingkungan Kerja Terhadap Kinerja Karyawan PT. Macanan Jaya Cemerlang Klaten - Jawa Tengah - Indonesia (Skripsi). Yogyakarta: Universitas Negeri Yogyakarta.

Sholikhah, M. S. H. (2015). Perencanaan Lama Waktu Istirahat Berdasarkan Beban Kerja dan Pengaruh Beban Kerja Terhadap Kelelahan (Studi Kasus di UKM pembuat tas UD. Harapan Baru) (Skripsi). Yogyakarta: Universitas Islam Negeri Sunan Kalijaga.

Sugiyono. (2018). Metode Penelitian

Kuantitatif Kualitatif dan R\&D. Bandung: Alfabeta.

Suma`mur. (2009). Hiegiene Perusahaan dan Keselamatan Kerja. Jakarta: CV. Sagung Seto.

Tarwaka. (2010). Ergonomi Industri. Dasar-dasar Pengetahuan Ergonomi dan Aplikasi di Tempat Kerja (Kedua). Surakarta: Harapan Press.

Tarwaka, H, S., A, B., \& Lilik, S. (2004). Ergonomi Untuk Kesehatan dan Keselamatan Kerja dan Produktivitas. Surakarta: UNIBA Press.
Wiratna, S. (2015). Metodologi Penelitian Bisnis dan Ekonomi. Yogyakarta: Pustaka Baru Press. 